\title{
Fictive Motion and Its Rhetorical Effect in Chinese Novels
}

\author{
Xiujun $\mathrm{He}$ \\ School of Foreign Languages, Lanzhou Jiaotong University, Lanzhou, Gansu, China
}

\begin{abstract}
Fictive motion is to represent stability by motion; it is first put forward by Talmy, who divided the fictive motion into five categories, that is to say, "emanation," "pattern paths," "frame-relative motion," "advent paths," "access paths," and "coextension paths.". Fictive motion is not only used in English, but also widely used in Chinese, especially in Chinese literary works, in which fictive motion has an intimate relationship with the figure of speech. The use of fictive motion and figure of speech make the works vivid and interesting. This paper intends to discuss the fictive motion and its rhetorical effect in Chinese novels.
\end{abstract}

Index Terms - fictive motion, Chinese novels, rhetoric effect

\section{INTRODUCTION}

Fictive motion is usually defined as the metaphorical motion of an object or abstraction through space, that's to say, a stationary situation is represented by the motion, and according to Talmy (2000), it can be divided into six categories. Because the motion is fictive, it is related to figure of speech to some extent, such as, simile, metonymy, exaggeration and so on. Fictive motion is a language phenomenon, so it not only exists in English, but also in Chinese, especially in literary works. The paper intends to analyze the fictive motion in Chinese novels, that's to say, what is the rhetorical effect of the figure of speech, how fictive motion and figure of speech co-worked to come to a certain kind of effect in Chinese novels.

\section{LITERATURE REVIEW}

Fictive motion is the metaphorical motion of an object or abstraction through space (Ramscar et al., 2009). Before the year of 2010, fictive motion had become a subject of study in psycholinguistics and cognitive linguistics. Some cognitive scientists who are interested in the dynamic imagery evoked by fiction motion also conducted investigations. Their investigation focused on whether and how dynamic imagery is evoked with the use of fictive motion. Reading tasks (Matlock, 2004), eye-tracking tasks (Richardson \& Matlock, 2007), and drawing tasks (Matlock, 2006) are main methods adopted in investigation.

In recent ten years, the study of fictive motion is still a subject of study in psycholinguistics and cognitive linguistics, and new experiment methods are adopted. Kim (2012) looked into the conceptualization process of fictive motion, Fan (2014) studied the cognitive elements in the motion event model of English fiction motion expressions of access paths, and Deng and Zhu (2020) investigated the processing of fictive motion and literal motion during natural language comprehension using electroencephalographic evoked response potentials. In addition, new research aspect emerged. Phenomenology was introduced into fictive motion (Blomberg \& Zlatev, 2014; Blomberg \& Zlatev, 2015; Shi, 2018). Fictive motion in specific genre of text, for example, alpine narratives, was investigated. Egorova et al. (2018) examined space properties that are highlighted through fictive motion in alpine narratives and further explained the motivation of communication underlying the use of fictive motion. With the use of fictive motion, not only the sense of a place but also the whole landscape of a motion event is conveyed to the reader. Egorova et al. (2018) developed rules for automated extraction and classification of three types of spatial descriptions in a corpus of alpine narratives. What's more, translation comparative study of fiction motion is also a popular perspective of research. Stojičić and Stamenković (2015) conducted an empirical study on encoding coextension paths in English (L2) to Serbian (L1) translation. Huang (2019) analyzed and compared the transition of the path and manner information of emanation fictive motions in two versions of Moment in Peking.

When it comes to research on mainland China, the fictive motion is not studied by linguists so much, and only a dozen of papers focused on this topic in recent ten years. Gao and Song (2010) believed that there is difference between language and reality, the still things in real world will have actions in language, their paper focused on the fictivity of fictive motion, the discourse features, and the rhetorical effects of fictive motion. Fan (2011,2012) focused on path and manner in English and Chinese fictive motion expressions of coextension paths, and on the abstractness of the two types of English coextension paths fictive motion expressions (arbitrary fictive motion and specific fictive motion expressions). Deng $(2012,2013)$ analyzed fictive motion of mental activity in English and Chinese from a cognitive perspective, and he also conducted a cognitive analysis of four subtypes in emanation fictive motion represented in Classic Chinese Song Poems. Yang $(2017,2020)$ carried out a comparative study on lexicalization patterns of fictive 
motion event in English and Chinese and probed the distribution and cross-language changes of fictive emanation paths between English and Chinese.

From the above statement, it can be seen that fictive motion is widely observed abroad, mainly adopted the theory of psycholinguistics and cognitive linguistics, but rare studies focused on rhetoric effect of fictive motion in literary works. Research of fictive motion is scarce in China, this paper attempts to reveal the use of fictive motion in Chinese novel, and how the use of fictive motion evokes a kind of rhetorical effect. It is hoped that it can be a complementary analysis to the previous researchers.

\section{Fictive Motion AND ITS CATEGORY}

Cognitive linguist Leonard Talmy proposed a unified account of the properties of fictive motion as they are expressed linguistically and perceived visually in his seminal book, Toward a Cognitive Semantics Vol.1, in 2000. "Fictive motion in language includes a number of relatively distinct categories. These categories are emanation, pattern paths, frame-relative motion, advent paths, access paths, and coextension paths" (Talmy, 2000, p.103). The emanation path is basically the fictive motion of an intangible entity emerging from a place. The category of emanation encompasses several relatively distinct types, such as "orientation paths," "radiation paths," "shadow paths," and "sensory paths". According to Talmy (2000), in most subtypes, "the intangible entity continues along its emanation path and terminates by impinging on some distinct object" (p.106). For example, in the radiation paths, the radiating event involves three entities: "the radiator, the radiation itself, and the irradiated object" (p.111). This radiating event then includes three processes: "the emanation of radiation from the radiator, the motion of the radiation along a path, and the impingement of the radiation on the irradiated object" (p.111). A typical example is: Light shine from the sun into the cave. Here, the radiator is the sun, and the irradiated object is the cave.

As to the pattern paths, it involves the fictive conceptualization of some configuration as moving through space, for instance, "As I painted the ceiling, paint spots slowly progressed across the floor." Here, the factive move is the falling of paint drop vertically downward to the floor, but each drop of paint does fictively move, and that motion is horizontally along the floor at any given time.

When it comes to frame-relative motion, people usually view things with the global frame as the reference, and then a language can factively refer to an observer as moving relative to her stationary surroundings. However, a local frame around the observer can also be regarded as the center. Within this frame, the observer can be depicted as stationary, and the factively stationary surroundings are represented as moving relative to the observer from her perspective. For instance, I sat in the car and watched the scenery rush past me. Here, "I" is represented as stationary, and the scenery is moving, although in fact, it is " $\mathrm{I}$ " that is moving. This kind of fictive motion is called frame-relative motion.

An advent path can be defined as "a depiction of a stationary object's location in terms of its arrival or manifestation at the site it occupies" (Talmy, 2000, p.134). An example will illustrate it explicitly, "The palm trees clustered together around the oasis." Here, the stationary state of the palm trees is factive, whereas the verb "cluster" is used for depicting a fictive motion: the palm trees move from the dispersed places to the locations around the oasis, but actually it is stationary.

Tamly (2000) defines an access path as "a depiction of a stationary object's location in terms of a path that some other entity might follow to the point of encounter with the object" (p.136). For example, "The bakery is across the street from the bank." This sentence depicts the location of the bakery in terms of a depicted path as if one person traverses from the bank to the bakery.

Co-extension path is the most widely used fictive motion in language; it can be defined as "a depiction of the form, orientation, or location of a spatially extended object in terms of a path over the object's extent" (Talmy, 2000, p.138). For instance, "The fence goes from the plateau to the valley." In this sentence, "the fence" is depicted as moving from the plateau to the valley, in fact, it is "our focus of attention, or perhaps some image of the fence itself advancing along its own axis, moves from one end of fence atop the plateau, along its length, to the other end of the fence in the valley" (Talmy, 2000, p.138).

The above is a brief introduction to the fictive motion and the six categories of fictive motion based on Tamly's theory. From the above description, we can draw a simple definition of fictive motion, that is, to depict the stationariness of a subject or situation through moving. What's more, this kind of language phenomenon is cognitively connected with metaphor, and the metaphorical devices in the fictive motion usually come to a special kind of rhetoric effect. The section below will discuss this question in detail.

\section{THE RHETORIC EFFECT OF FiCTIVE MOTION}

In Chinese novels, the figure of speech is widely used to make the works more attractive and readable. If we closely observe the figure of speech, we can see some of them are related with fictive motion, and the fictive motion is the underlying mechanism of figure of speech. Using fictive motion, that's to say, using certain kind of figure of speech, a certain kind of rhetoric effect is attained.

\section{A. Conceit and Fictive Motion}


In literature, a conceit is an extended metaphor with a complex logic that governs a poetic passage or entire poem. By juxtaposing, usurping, and manipulating images and ideas in surprising ways, a conceit invites the reader into a more sophisticated understanding of an object of comparison (https://encyclopedia.thefreedictionary.com/Conceit). A fanciful or unusual image in which apparently dissimilar things are shown to have a relationship. The conceit, this kind of figure of speech is widely used in Chinese, and it is closely related to fictive motion. The following are some examples:

(1) 一条泥路从雪地里挣扎出来, 它被大雪捂了一个长冬了。它又活了过来, 在牛蹄儿下扭来扭去, 一直通 向地头。(《太平土》)

（2）地上, 油淢淢的, 一摊一摊, 摊着从窗外涌进的阳光。(《想象一个歌手》)

The first sentence can be regarded as the co-extension path in the fictive motion. In this sentence, we have a factive characterization of “泥路” as a stationary object with linear extension and with a particular outline of its shape, orientation, and position in geographic space. However, through the use of conceit, “泥路” is represented as an animal, whose images are absolutely different from each other, we have the fictive representation evoked by the literal sense of the sentence, in which the image of “泥路”, which can also be said the animal advancing along its own axis, moves from here to “地头”.

The second sentence can be categorized as the radiation path in emanation. In this sentence, “阳光” is compared to “油”, and two absolutely different images are mixed together to give us the fictive motion of “阳光”. Using conceit, the image of the things in the sentence can be expressed vividly and explicitly.

\section{B. Simile and Fictive Motion}

A simile is a figure of speech that says that one thing is like another different thing. We can use similes to make descriptions more emphatic or vivid (https://encyclopedia.thefreedictionary.com/simile). Simile is also widely used in fictive motion in Chinese novels through the use of words like “像”, “似的”.

(1) 哪怕是在她的背后, 她也能感觉到他的眼光一波一波的像飞镖似的打过来。(《明惠的圣诞》)

（2）土地被打开了, 土腥味喷涌而出, 潮水一样往犁铧上扑。(《太平土》)

（3）皎洁的明月高挂在淡蓝色的天空中, 月光像流水一样泻下来, 大地一片银白色。（《少年闰土》）

In the first example, “眼光” is compared to “飞镖”, the sentence can be categorized as the sensory path in the emanation. “眼光” is represented as if moving to her. The second example is also the sensory path in the fictive motion, what makes it different from the first one is that it is concerned with smell, while the first one is related to sight. In the third sentence, “月光” is compared to “流水”, it is contained in the radiation category of fictive motion. “明月” is the radiator, “月光” is characterized as moving as “流水”. With the use of simile, the descriptions can be more emphatic and vivid.

\section{Metonymy and Fictive Motion}

Metonymy is a figure of speech that has to do with the substitution of the name of a thing or concept for that of another, which is closely related with that thing or concept. In language, metonymy is a kind of language phenomenon in which one word or phrase is replaced by another to which it is intimately related, and the transference of a name from one thing to another is based on several definite kinds of associations: designating the effect with the cause, the whole with a part, the contents with its container. A fictive motion can be realized with the use of metonymy, in such cases, one concept or word that is stable is represented by another thing or concept, which can give us a sense of motion. The following are some examples:

(1) 后来只见我眼前突然出现了忽悠悠的一条路。(《村经》)

(2) 眼睛从二妹子头上滚到脚底, 再从脚底滚到头上。(《一束槐香》)

In the first sentence, “忽悠悠的” can not be “一条路”, it must be the people on the road, so “路” is represented by people on it. This sentence can be categorized as the co-extension path in the fictive motion, and using metonymy, we get the road's location in the geographic space. The second example is a typical type of sensory path in the emanation path, with the use of verb “滚”, we get a kind of impression that the eyes are moving, though actually it is still. It is the sight that is moving rather than eyes. Just as Panther and Radden (1999) figured out: "along with other figurative modes of thought, metonymy is commonly used to produce rhetorical effects as in humor, jargon, literature, persuasion, slang, poetry, and the like. The rhetorical effects tend to derive from violations of default cognitive and communicative principles" (p.37).

\section{Exaggeration and Fictive Motion}

Exaggeration is perhaps the most familiar figure of speech that we know, it is a representation of something in an excessive manner, and it means the describing of something and making it more than it really is. People use exaggeration for they have strong feelings about one thing to express. They may use exaggeration to attract hearers' attention so that the hearers would listen to what they say. They may use it to stress something. They may also use it just to reach the effect of being funny. Exaggeration is often co-used with fictive motion to reach a certain kind of rhetorical effect, for example: 
(1) 妇人一个眼波荡过来, 差点没把轮椅掀翻。(《红漆雕花窗》)

（2）春秧抬头看，黑楼道穿破楼顶要通到天上去。(《金地》)

The first example can be viewed as the sensory path in the emanation path of fictive motion, actually “眼波” is stable, but with the use of the word “荡” and “掀”, it seems that the sight is something active, and it gives us the sense of fictive motion. In the second sentence, the stable “黑楼道” is represented as taking an action, and it extends to the sky. With such kind of exaggeration in accompany with fictive motion, we get the physical location of "楼道" in the geographic world. With the use of fictive motion, a kind of exaggeration is achieved, thus the novel can be more attractive and vivid.

\section{E. Personification and Fictive Motion}

Personification is also called anthropomorphism, which is a figure of speech in which an animal, idea, phenomena, object etc. is given an attribution of human characteristics (or characteristics considered belong only to humans). To be simple, it is the act in speech and writing in which human characters are attributed to nonhuman things. The writers can create life and motion within inanimate objects, and even within abstract concepts or actions. Fictive motion will use this figure of speech to regard the things as person, for example:

(1)于是, 商店、旅馆、饭馆、茶馆、学校、澡堂子、理发店、大车店以及逢五的大集, 都跟踪而至了。(《壶 嘴儿》)

(2)但是一颗大树挡住了去路，它伸出一根树枝温柔地将箩筐挂在上面。(《布景》)

(3)路从山上下来。越过一片挺杆溜直的水冬瓜树林, 在几株两米多高盛开着白喇叭花的大百合旁边走过, 一 个大坡翻下去。忽地加快了速度, 消失在翻滚的陡然上涨的江水。(《系着野牛皮筋的旅游鞋》)

(4)土地把一朵花、一枚果子高高的举起来, 就像自己的女人把自己生下来的孩子抱给丈夫看。(《太平土》)

(5)惊慌失措的芬芳, 在空气中四处迸溅。(《系着野牛皮筋的旅游鞋》)

The first example can be viewed as the advent path in fictive motion, the stationary state of “商店、旅馆、饭馆、茶 馆、学校、澡堂子、理发店、大车店以及逢五的大集” is fictive, in fact, there is no motion of these things at all. However, the verb “跟踪” is used, it is as if “商店、旅馆、饭馆、茶馆、学校、澡堂子、理发店、大车店” moved from behind secretly. The second example is the advent path, “大树” and “树枝” are factive and stationary, but the use of the verb “挡” and the adjective “温柔” give us a sense of human being, especially the use of the “挡” give us a kind of feeling that the tree comes from somewhere else to intentionally disturb you, but actually it is stationary. The third sentence is a typical example of co-extension path, the use of verb “下”, “越过”, “走过”, “翻” and “加快” give us the impression that the road is moving, although it is still as it is, actually it is the image of the road that advance along its own axis. Using such kind of words, the image of the road as a stationary object with linear extension and specific outer edge, orientation, and specific location is given to us. As to the fourth sentence, it is hard to trace it to a certain category, it seems that it is more rational to attribute it to the access path in the fictive motion, but it is certain that there is fictive motion because “土地”, “花” and “果子” are all stationary, but with the use of verb “举”, it seem that the earth has an action of raising. The last one can be viewed as the sensory paths in emanation. In fact, that kind of smell is stationary, while with the use of words “惊慌失措” and “迸浅”, it gives us a kind of fictive motion. In the literature writing, especially the novels, the authors usually use personification to add interest and color to their writing, and to make it more interesting and amusing. Readers are given more vivid examples and images.

\section{F. Synaesthesia and Fictive Motion}

Synaesthesia is a neurologically based perceptual phenomenon in which the stimulation of one sense causes the automatic experience of another sense, as when the hearing of a sound produces the visualization of a color. To be simple, it can be defined as union of the senses, since the usually separately experienced senses are joined together unconsciously and naturally. The sensory path in the fictive motion is closely related to the synaesthesia, the following are two examples:

(1)吴少夜大喊一声, 他的声音顺着窗户爬出去, 毫不客气地在那男人耳上咬了一口。(《红漆雕花窗》)

(2)䉽蛋捅了捅发呆的吴少爷，示意他用目光去抚摸那红润的脸庞。(《红漆雕花窗》)

(3)叫声划破了玻璃窗。(《南风》)

The above three sentences can be all characterized into the sensory path in the emanation of fictive motion. “声音”, “目光”, and “叫声” are all represented as moving with the use of verbs. In the first sentence, the verbs “爬” and “咬” are used, the sound leads to the automatic, involuntary experiences in a second cognitive pathway, so it used the figure of speech, synaesthesia, in this sentence, and it gives us a sense and impression of motion. The second and third sentences are the same as the first one. The use of synaesthesia can break through the limitations of language and make the language more readable and interesting.

\section{CONCLUSION}

The theory of Tamly's fictive motion is the basis of some kinds of figure of speech, his five categories can account 
for the rhetoric reasonably. Just as the paper shows that it co-effected with rhetorical devices such as simile, metonymy, conceit, exaggeration, personification, synaesthesia etc. to enhance the readability of novels. With the use of such devices, the novel is more vivid and attractive. Thus, here, a conclusion can be drawn that the fictive motion should be used in the writing of the novels, and the writer should pay more attention to the conceptual structure of the sentence, so that inspiration could occur. Another implication is that the fictive motion should be studied more deeply and over whole, because the theory is the root of practice. More searches should be conducted to see whether there is deep relationship between fictive motion and figure of speech.

\section{REFERENCES}

[1] Blomberg, J., \& Zlatev, J. (2014). Actual and non-actual motion: why experientialist semantics needs phenomenology (and vice versa). Phenomenology and the Cognitive Sciences, 13(3), 395-418.

[2] Blomberg, J., \& Zlatev, J. (2015). Non-actual motion: phenomenological analysis and linguistic evidence. Cognitive Processing, 16 Suppl 1(Suppl.), 153-157.

[3] Conceit, Retrieved July, 29, 2021, from https://encyclopedia.thefreedictionary.com/Conceit

[4] Deng, Y. (2012). A cognitive approach to fictive motion of mental activity in English and Chinese. Journal of Guangzhou University (Social Science Edition), 11(10), 59-63.

[5] Deng, Y. (2013). A cognitive analysis of emanation fictive motion in Chinese song poems. Journal of Xihua University (Philosophy \& Social Sciences), 32(6), 70-74.

[6] Deng, Y., \& Zhu, H. L. (2020). To move or not to move: An ERP study on the processing of fictive and literal motion expressions. Lingua, 244, 1068-1097.

[7] Egorova, Tenbrink, \& Purves. (2018). Fictive motion in the context of mountaineering. Spatial Cognition \& Computation, 18(4), 259-284.

[8] Egorova, Moncla, Gaio, Claramunt, \& Purves. (2018). Fictive motion extraction and classification. International Journal of Geographical Information Science, 32(11), 2247-2271.

[9] Fan, N. (2011). Path and manner in English and Chinese fictive motion expressions of coextension paths. Journal of Dalian Maritime University (Social Sciences Edition), 19(2), 106-109.

[10] Fan, N. (2012). A study on abstractness of English coextension paths fictive motion expressions. Foreign Language Education, $33(2), 40-43$.

[11] Fan, N. (2014). The study of motion event model and cognitive mechanism of English fictive motion expressions of access paths. Theory and Practice in Language Studies, 4(11), 2258-2264.

[12] Gao, Y., \& Song L. M. (2010). The rhetorical effect of fictive motion. The Chinese, 20, 1-2.

[13] Gunter, R., \& Zoltan, K. (1999). Metonymy in language and thought. John Benjamins Publishing Company.

[14] Huang, N. (2019). Translation comparison about manner and path of emanation fictive motions in Moment in Peking -illustrated by Two Versions Translated by Zhenyu Zhang and Fei Yu. International Journal of Linguistics, Literature and Translation, 2(5), 373-379.

[15] Kim, J. H. (2012). Cognitive process of fictive motion. The Journal of Linguistics Science, 60, 109-126.

[16] Matlock, T. (2004). Fictive motion as cognitive simulation. Memory \& Cognition, 32(8), 1389-1400.

[17] Matlock, T. (2006). Depicting fictive motion in drawings. In J. Luchenbroers (Eds.), Cognitive Linguistics: Investigations across languages, fields, and philosophical boundaries (241-252). Amsterdam: John H. Benjamins.

[18] Ramscar, M., Matlock, T., \& Dye, M. (2009). Running down the clock: The role of expectation in our understanding of time and motion. Language and Cognitive Processes, 25(5), 589-615.

[19] Richardson, D., \& Matlock, T. (2007). The integration of figurative language and static depictions: An eye movement study of fictive motion. Cognition, 102(1), 129-138.

[20] Shi, L. H. (2018). Introducing Phenomenology into Fictive Motion. Paper presented at 2nd International Conference on Culture, Education and Economic Development of Modern Society (ICCESE 2018), Moscow, Russia.

[21] Simile, Retrieved July, 29, 2021, from https://encyclopedia.thefreedictionary.com/simile

[22] Stojičić, V., \& Stamenković, D. (2015). Cross language research on encoding coextension paths in English (L2) to Serbian (L1) translation: an empirical study. Science, 24(4), 635-645.

[23] Talmy, L. (2000). Toward a Cognitive Semantics (Vol. 1). MA: MIT Press.

[24] Yang, J. P. (2017). A comparative study on lexicalization patterns of fictive motion event in English and Chinese: Taking "toward(s)" as the example. Foreign Language Teaching and Research (bimonthly), 49(1), 15-26.

[25] Yang, J. P. (2020). An Empirical Study on Emanation Fictive Motion in English and Chinese: Taking "toward(s)" as the example. Foreign Language Education, 41(3), 47-51.

Xiujun He was born in Tianshui City, Gansu Province, China in 1989. She obtained her M.A. in foreign linguistics and applied linguistics from the School of Foreign Languages, Beijing University of Aeronautics and Astronautics, China in 2013.

She is a lecturer in the School of Foreign Languages, Lanzhou Jiaotong University, Gansu, China. Her main research interests lie in cognitive linguistics and contrastive linguistics 